\title{
Application of Geo-Processing Model for a Quantitative Assessment of Coastal Exposure and Sensitivity to Sea Level Rise in the Sultanate of Oman
}

\author{
Salim Al-Hatrushi, Elnazir Ramadan, Yassine Charabi \\ Department of Geography, Sultan Qaboos University, Muscat, Oman \\ Email: hatrushi@squ.edu.om, alnazir@squ.edu.om, yassine@squ.edu.om
}

Received 25 May 2015; accepted 5 September 2015; published 8 September 2015

Copyright (C) 2015 by authors and Scientific Research Publishing Inc.

This work is licensed under the Creative Commons Attribution International License (CC BY). http://creativecommons.org/licenses/by/4.0/

\section{(c) (i) Open Access}

\begin{abstract}
The Sultanate of Oman has a long coastline extending for about $3165 \mathbf{~ k m}$ including a number of bays and islands. Oman's coastline borders the Arabian Gulf, the Sea of Oman and the Arabian Sea. Most of this coastline is soft and low laying shore subject to the dynamics of sediment transport and the landward retreat of the shoreline, caused by anthropogenic factors and sea level rise associated with climate change. This paper aims to assess the vulnerability of the entire Omani coastal zone to the expected sea level rise and storm surge. Methodology is based on applying Coastal Vulnerability Index (CVI) to identify clusters of high vulnerability areas according to their sensitivity and dynamic nature and increased risk resulted from seal level rise, erosion and extreme weather events. The coastal line of the governorates of Al Batinah, Muscat and Al-Wusta has scored highly due to possessing similar physical attributes. Based on that assessment a coastal vulnerability database utilizing GIS was created to help stakeholders involved in the coastal management to make better decisions.
\end{abstract}

\section{Keywords}

Sea Level Rise, CVI, Coastal Vulnerability, Sultanate of Oman

\section{Introduction}

Sea level rise in the present time represents one of the most significant climate change indicators that affect coastal areas. It is expected to continue rising and possibly accelerate in the future due to the increase in the av- 
erage global surface temperature, and influences from changes in ice sheet dynamics. The global mean sea-level rise situation actually results from thermal expansion as well as ice melt. Knowledge of these processes is quite essential and represents an appealing area of research for assessment of coastal vulnerability to climate change. The Intergovernmental panel on climate change (IPCC) reports defines vulnerability to climate change as the degree to which a system is susceptible to, and unable to cope with, adverse effects of climate change, including climate variability and extremes. According to the IPCC vulnerability is a function of the character, magnitude, and the rate of climate change to which a system is exposed, its sensitivity, and its adaptive capacity [1]. The assessment may include already implemented measures as well as scenarios of future adaptation.

Coastal geomorphic processes of erosion and accretion and sea level changes continuously modify the shoreline. The primary causes of coastal erosion and landward retreat of the shoreline are direct wave action, the interception of littoral drift, sea level rise, and human interference. The sea level rise at any particular location is controlled by processes such as melting of polar ice caps and glaciers, changes in sea temperature and thermal expansion, seafloor spreading and undersea volcanism, changes due to localized subsidence or uplift of the coastline, and changes from the deposition of sediment. Ocean thermal expansion and high waves associated with extreme meteorological events (atmospheric depressions) can also cause temporary coastal erosion [2].

The Sultanate of Oman has an extended coastline extending for about $3165 \mathrm{~km}$ including a number of pays and islands. Most of this coastline is soft and low laying shore subject to the dynamics of sediment transport and landward retreat of the shoreline caused by anthropogenic factors such as coastal engineering activities, and natural processes such as sea level rise associated with climate change. Despite their buffer role and resilience, low laying sandy coasts and the associated tidal inlets, coastal lagoons and the adjacent salt flats and coastal sabkhas, which are numerous around the coast of Oman, may not be stable in the long term. They are subject to change in their morphology by coastal geomorphic processes of erosion and accretion caused by sea level changes which continuously modify the shoreline.

This paper aims to assess the vulnerability of the entire Omani coastal zone to the expected sea level rise, and ocean thermal expansion and high waves associated with extreme meteorological events (atmospheric depressions) throughout the calculation of The Coastal Vulnerability Index (CVI). CVI is one of the most commonly used and simple methods to assess coastal vulnerability to sea level rise. Spatial analysis conducted within a Geographical Information System (GIS) employing geo-processing tools (e.g., buffering, overlay, union/intersection, interpolation) allows researchers to quantitatively assess the vulnerability of coastal areas. A geoprocessing model consists of one or more algorithms that create new spatial data from specified input data to calculate the CVI [3].

\section{Study Area}

Oman's coastline borders the Arabian Gulf in the North and northwest, Sea of Oman in the northeast and the Arabian Sea in the southeast (Figure 1). The low laying coastal areas in Oman support a significant proportion of the population in Oman. According to 2010 national censes, Al Batinah coastal plain and the adjacent Muscat Governorate accommodates 56\% of Oman's population making it the most density populated region in the Sultanate. Furthermore, Salalah coastal plain, which is also soft and low laying shore, accommodates 8\% of Oman's population. The low laying coastal areas in Oman have been experiencing rapid development over the past four decades. Infrastructures, including roads, corniches, hotels and tourism activities, residential houses, desalination plants, ports and fishing harbors are constructed along the coast. Such areas could be threatened by sea level rise. Furthermore, during the last couple of years the Sultanate of Oman has witnessed two strong tropical cyclones, Gonu 2007 and Phet 2010 which caused severe damages estimated at 5 billion USA and revealed the extreme vulnerability of the populated Omani coast to storm surge and flooding [4]. Even, without the impacts of extreme events, the coastal cities in Oman are currently exposed to flooding, erosion, and salinization of ground and surface water. The current hazard and the growing risk of the Omani coast, call for an application of geoprocessing model for a quantitative assessment of coastal exposure and sensitivity to Sea Level Rise.

Studies on coastal erosion and landward retreat of the shoreline in Oman are limited and mainly investigating coastal erosion in Al Batinah. [5] reported an extensive study on the statues of erosion along the coasts of Oman. They concluded that some coastal areas in Oman are experiencing severe erosion due to reduction in sediment supply by recharge dams and roads, construction of harbors and the long-term process of sea level rise. Badenhorst [6] considered the Al Batinah coast to be in a state of widespread erosion with recharge dams, sea level rise and harbour construction all being possible causes. In their Environmental Impact Assessment, Atkins [7] 


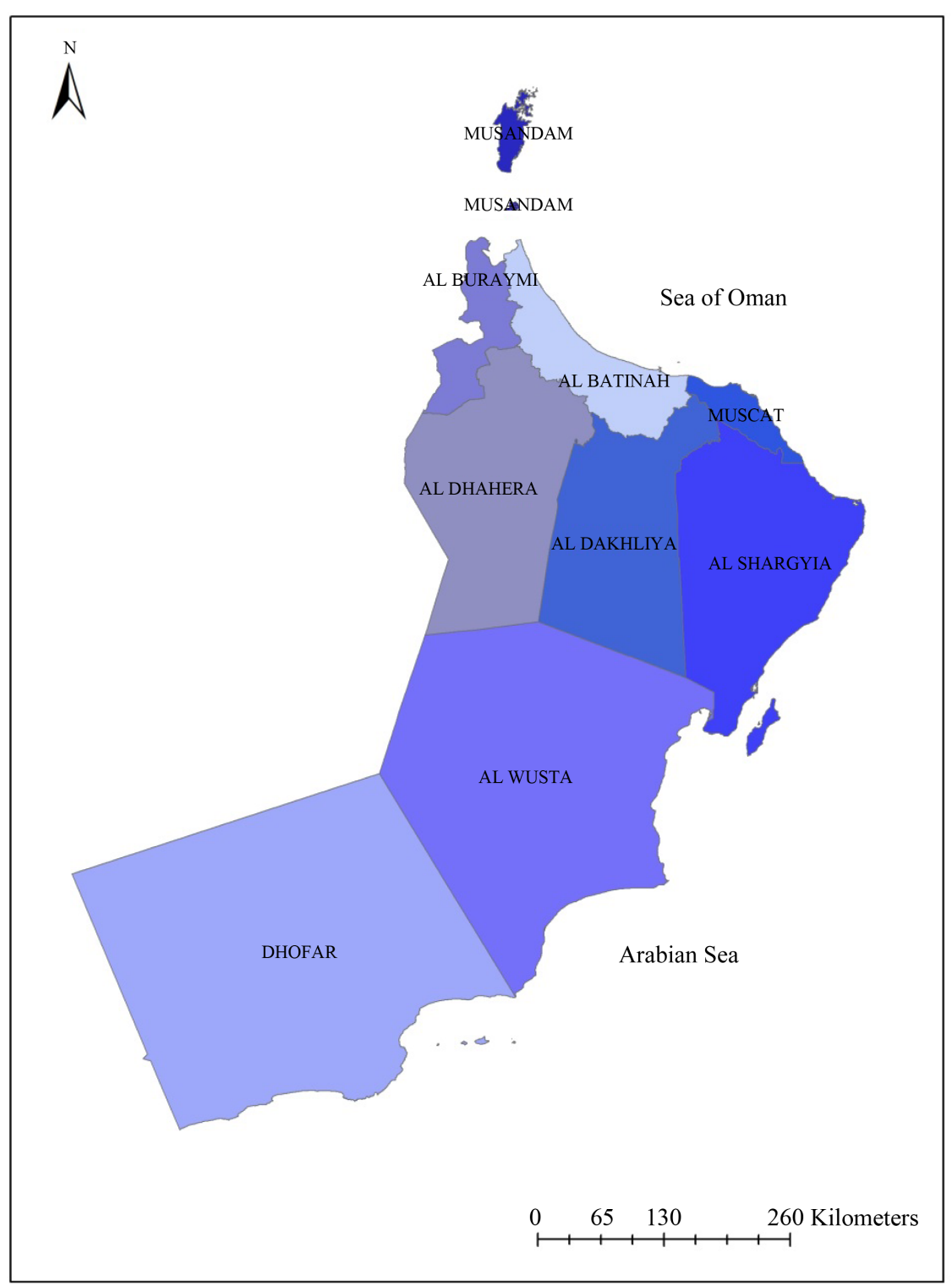

Figure 1. Location of the study area.

investigated the coastal area adjacent to Sohar Industrial Port. They have related the existed coastal erosion problem mainly to the coastal engineering activities such as harbor development. Al-Hatrushi [8] investigated the status of coastal erosion in Al Batinah and suggested that Al Batinah sandy shoreline is generally stable. However, local interruption of longshore transport by coastal engineering structures has caused limited erosion and accretion on short temporal and spatial scales. Erosion related to natural processes such as sea level rise was not investigated in this study.

\section{Data Sets and Methodology}

The overall aim of coastal vulnerability assessments are to act as guidance for scientists, coastal managers and decision makers to consolidate their knowledge on where along the coastline the impacts of Sea Level Rise (SLR), climate change and other non-climate drivers will be most keenly felt. A common form of coastal vulnerability assessment involves calculating an index, a method that can simplify a number of complex and interacting parameters, represented by diverse data types, to a form that is more readily understood and therefore has greater utility as a management tool. 
The first Coastal Vulnerability Index (CVI) focusing on the effects of SLR (particularly inundation and erosion) was developed by Gornitz (1990). This CVI used six physical variables as indicators of a coastline's vulnerability to the impacts of SLR: geomorphology, coastal slope, rate of relative sea-level rise, rate of shoreline erosion/accretion, mean tide range and mean significant wave height. The CVI is calculated as the square root of the product of six variables, ranked from 1 to 5 according to Table 1, and divided by their total number (Equation (1)) [9]

$$
C V I=\sqrt{(\text { a.b.c.d.e.f }) / 6}
$$

where,

a: geomorphology,

$b$ : coastal slope,

$c$ : rate of relative sea-level rise,

$d$ : rate of shoreline erosion/accretion,

$e$ : mean tide range,

$f$ : mean significant wave height.

For the calculation of the CVI for the entire coastal area of Oman, data were collected from different sources and complied into GIS database. The geomorphological variables were collected from detailed geomorphological map (at a scale of 1/10,000) carried out on 1986, in the framework of coastal zone management plans and Oman comprehensive national coastal erosion prevention strategy and action plan, for Ministry of Regional Municipalities and Environment. Furthermore, geological developments along the shoreline were recognized using geological maps of the Ministry of Commerce and Industry that have a scale of $1 / 100,000$. The incline of the coastal zone was measured using the Digital Elevation Model (DEM) of Oman with 4 m contour interval (1 $\mathrm{m}$ for the low lying coastal plains) obtained from the National Authority Survey. In order to estimate the gradient of the sub-aerial coastal zone the slope of each grid cell with $40 \times 40$ m mass was measured by identifying elevation limits.

For the sea level change, we have considered only the changes due to eustatism component, since there are no historical records of variable in Oman. For shoreline erosion or accretion rate were derived from previous studies. The mean annual values of significant wave height and tidal Datum have been obtained from the Oman National Hydrographic Office. The assumed tidal range in the Sea of Oman was 0.89 to 1.70 meters. Since 1990, Chart Datum has been established at over 40 sites along Oman's coast from observations conducted by, or under the supervision of, the Royal Navy of Oman's Hydrographic Department (Oman National Hydrographic Office, 2012). Each variable for each coastal segment has been ranked from 1 (very low) to 5 (very high) vulnerability, according to the values provided by Thieler and Hammar-Klose [9] and presented in Table 1. Subsequently the CVI value for each coastal segment was calculated using Equation (1) in order to have a preliminary assessment of the impacts of sea level rise on coastal areas of Oman.

Table 1. Ranges for vulnerability ranking of the six variables used in Equation (1) (Thieler and Hammar-Klose, 1999).

\begin{tabular}{|c|c|c|c|c|c|}
\hline \multirow{2}{*}{ Variable } & Very low & low & Moderate & High & Very high \\
\hline & 1 & 2 & 3 & 4 & 5 \\
\hline Geomorphology & $\begin{array}{l}\text { Rocky, cliffed } \\
\text { coasts }\end{array}$ & Medium cliffs & Low cliffs & $\begin{array}{l}\text { Cobble beaches, } \\
\text { Estuary }\end{array}$ & $\begin{array}{c}\text { Barrier beaches, } \\
\text { Sand beaches }\end{array}$ \\
\hline Coastal slope (\%) & $>12$ & $12-9$ & $9-6$ & $6-3$ & $<3$ \\
\hline $\begin{array}{l}\text { Relative sea level change } \\
\qquad(\mathrm{mm} / \mathrm{yr})\end{array}$ & $<1.8$ & $1.8-2.5$ & $2.5-3.0$ & $3.0-3.4$ & $>3.4$ \\
\hline $\begin{array}{l}\text { Shoreline erosion/accretion } \\
\qquad(\mathrm{m} / \mathrm{yr})\end{array}$ & $\begin{array}{c}>2.0 \\
\text { Accretion }\end{array}$ & $\begin{array}{l}1.0-2.0 \\
\text { Accretion }\end{array}$ & $\begin{array}{l}-1.0-+1.0 \\
\text { Stable }\end{array}$ & $\begin{array}{l}-1.1-2.0 \\
\text { erosion }\end{array}$ & $\begin{array}{l}<-2.0 \\
\text { erosion }\end{array}$ \\
\hline Mean tide range (m) & $>6.0$ & $4.1-6.0$ & $2.0-4.0$ & $1.0-1.9$ & $<1.0$ \\
\hline Mean wave height (m) & $<0.55$ & $0.55-0.85$ & $0.85-1.05$ & $1.05-1.25$ & $>1.25$ \\
\hline
\end{tabular}




\section{Results and Discussions}

The obtained CVI values along the coastline of Oman vary between 0.32 and 8.35 , the median value of the index for the whole study area is 3.81 while the stander deviation is 1.89 . The spatial spread of the vulnerability of the coastal line of Oman to the potential sea level rise is presented in Figure 2.

For the coastline of Musandam Governorate $21.1 \%$ was classed as very highly vulnerable to SLR coastline which is flanked by the Arabian Gulf in the west, the Sea of Oman in the east and the Strait of Hormuz in the north, is rocky, steep and mountainous. However, sand beaches occur on the Arabian Gulf side, while pocket beaches occur in the east side with sediments derived from near shore source. Numerous small wadis dissect the highly concave shoreline of Musandam which have gravel and sandy beaches.

The CVI classes for the six coastal governorates in the Sultanate of Oman shows that Al Batinah coastline which is located in the northeastern part of the Sultanate of Oman, bounded between the Western Hajar Mountain Range and the Sea of Oman, is the most vulnerable to the SLR (98.5\% very highly vulnerable). It extends in a NW-SE trend as a crescent shape and parallel to the mountains for about $230 \mathrm{~km}$ from UAE border in the NW to Ras al Hamra in Muscat in the SE. The AlBatinah coast is predominantly non-indented alluvial fans, and characterized by longshore sand transport along a low lying coastal plain fringed by beaches and dunes. The coastal plain is narrow at its northern and eastern ends, while its width in the middle is around $50 \mathrm{~km}$. The coastal plain is composed of continuous alluvial fans drained from the mountains with sediment which varies from gravel and coarse sands to fine sands and silt near the coast. This suggests that most of the beach sediments along the coast are of terrestrial origin [10].

For Muscat Governorate, $47.5 \%$ of the coastline was considered as very highly vulnerable to the SLR. These rates rank the governorate in the second position in term of high vulnerability after Al Batinah Governorate. The coastline between Muscat and Ras al Hadd is a steep cliffed coast with wadis breaking through the raised shore platforms, and some small pocket beaches. The cliffed coast continues south until it gives way to Al Sharqiya Sands, which are predominantly non-indented flat beaches covered by beach ridges

Al Sharqiyah coastline is a steep cliffed coast stretches for approximately $200 \mathrm{~km}$ along the southeastern part of the Sea of Oman. It trends from Ras al Hamra in Muscat to Ras al Hadd in the southeast. Although it is rocky, there are some indentation areas in the major khawrs and embayment's such as Bandar Al Khairan, Khawr Al Batih, Khawr Jaramah and Khawr Al Hajar. Furthermore, sandy and gravel beaches composed one third of the coastline.

For Al-Wusta Governorate, $45.4 \%$ and $18.3 \%$ of the coast line were considered as very highly and highly vulnerable to SLR. The coastline adjacent to Al Sharqiyah Sands extends south to Barr al Hikman is low lying and characterized by a wide continental shelf with flat beaches covered by beach ridges and sand dunes of offshore source. The coastline between Barr al Hikman Peninsula and Ras Mudrakh is extremely flat sandy coast with beach ridges caused by increasing sand deposit. Farther south, low cliffs are existed and with slightly indented sandy beaches, coral reefs, coastal sabkhas and tidal flats.

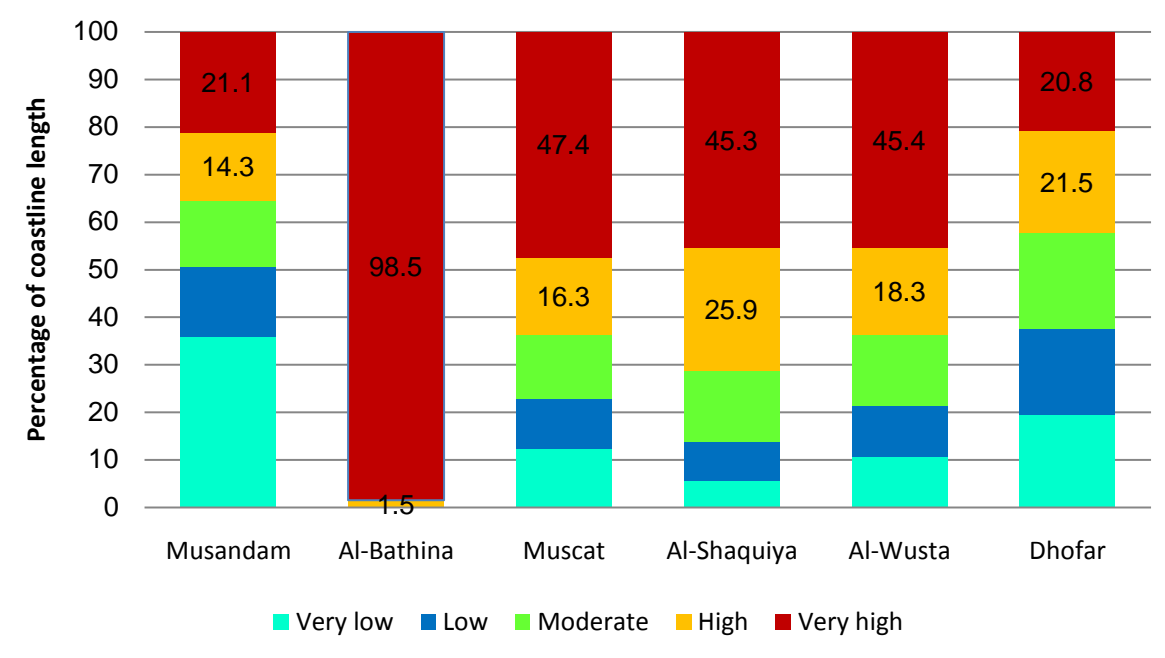

Figure 2. CVI classes for the six coastal governorates of the Sultanate of Oman. 
For Dhofar Governorate, the percentage of the very highly vulnerable class to SLR is the lowest comparing to the rest of the governorates. Dhofar coastline extends south to the border with Yemen Republic. It contains high mountain cliffs with enclosed sand beaches and the relatively wide Salalah coastal plain. The Salalah coastal plain extends approximately $50 \mathrm{~km}$ between Taqa and Raysut. It is low-laying sandy coast with many scattered lagoons and tidal inlets that support mangrove stands. To the east and west of it, steep cliffed coasts dominate the area with numerous wadi mouths [11].

\section{Conclusions}

The objective of this article was to apply a CVI to the coastal area of Oman. Upon the application of CVI, clusters of high vulnerability areas were identified according to their sensitivity and dynamic nature. Furthermore increased risks from seal level rise, erosion and extreme weather events were also considered. The coastal line of the governorates of Al-Bathina, Muscat and Al-Wusta has scored high due to the fact that they enjoy similar physical attributes.

Based on that investigation and assessment, a coastal vulnerability database utilizing GIS software was established. This database represents a valuable tool for stakeholders involved in the coastal management. With this database, information could be added and updated when it becomes available therefore making the tool both upto-date and incessantly appropriate. Eventually the application of CVI methods to the coastline of Oman has great potentialities. As a tool it has the ability to be incorporated into an overall coastal management strategy, enabling an effective dynamic management of coastal area of Oman.

\section{References}

[1] Lambeck, K., Esat, T.M. and Potter, E.K. (2002) Links between Climate and Sea Levels for the Past Three Million Years. Nature, 419, 199-206. http://dx.doi.org/10.1038/nature01089

[2] Warrick, R.A., Provost, C.L., Meier, M.F., Oerlemans, J. and Woodworth, P.L. (1996) Changes in Sea Level. In: Climate Change 1995: The Science of Climate Change, 359-405.

[3] Thieler, E.R. and Hammar-Klose, E.S. (1999) National Assessment of Coastal Vulnerability to Sea-Level Rise, U.S. Atlantic Coast. US Geological Survey, Open-File Report, 99-593.

[4] Stive, M.J.F., Roelvink, J.A. and De Vriend, H.J. (1990) Large-Scale Coastal Erosion Concept. 22nd Coastal Engineering Conference, New York, 1962-1974.

[5] Dobbin, J. Associates Inc. (1992) Coastal Erosion in Oman. Report for the Ministry of Regional Municipalities \& Environment, Muscat, Sultanate of Oman.

[6] Badenhorst, P. (1995) Erosion along the Batinah Coastline. CSIR/GPS Report, Spp.

[7] Hayes, M.O. and Baird, W.F. (1993) Shoreline Erosional/Depositional Patterns in Oman. Proceedings of Coastal Zone 93, Volume on Coastal Engineering, New Orleans, 144-158.

[8] Al-Hatrushi, S.M., Kwarteng, A.Y., Sana, A., Al-Buloushi, A.S., MacLaclan, A. and Hamed, K. (2014) Coastal Erosion in Al Batinah, Sultanate of Oman. Academic Publication Board, Sultan Qaboos University, Muscat, 261.

[9] Gornitz, V. (1995) Sea-Level Rise: A Review of Recent, Past and Near-Future Trends. Earth Surface Processes and Landforms, 20, 7-20. http://dx.doi.org/10.1002/esp.3290200103

[10] Al-Hatrushi, S.M. and Al-Buloshi, A.S. (2009) Coastal Erosion and Its Impact on Society on the Batinah Coast, Sultanate of Oman. Geographische Rundschau International Edition, 5, 12-17.

[11] Atkins (2002) Shoreline Evolution Report. Sohar Port Project, Batinah Coast Oman. Final Report for the Ministry of Regional Municipalities \& Environment, Muscat, Sultanate of Oman. 